\title{
EFEKTIVITAS PIJAT UNTUK MERANGSANG HORMON OKSITOSIN PADA IBU NIFAS PRIMIPARA
}

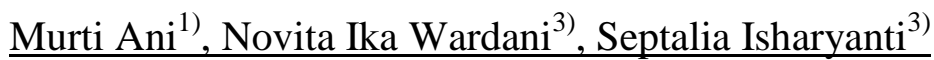 \\ murtiani89@yahoo.com
}

\begin{abstract}
AB STRACT
Maternal mortality in Indonesia is still quite high, one reason is postpartum hemorrhage. Efforts to prevent postpartum hemorrhage can be done with the administration of oxytocin. The hormone oxytocin plays a role in the process of return of the uterus to its original shape. Oxytocin is also working spur spending reflex ASI Let Down Reflex (LDR).

To examine the effectiveness of massage to stimulate the hormone oxytocin in the mother postpartum primipara

This quasi-experimental research designs, sampling techniques with simple random sampling of 60 people, 30 people in treatment group and 30 controls. The research instrument that is the observation sheet. The massage is done every day, from day 1 to day 14 post partum. TFU measurement observations, kind lochea, weight baby day 1, 4, 7, 10, 14. Statistical test with Mann Whitney.

Massage to stimulate the oxytocin hormone has a high effectiveness against changes in the uterine fundus on the day 7 and 10 of 0.023 and 0.0001 (p $<0.05$ ), to change the type of lochea on the day 4, 7, 10, 14 amounted to 0.015 , $0.001,0.000,0.000(\mathrm{p}<0.05)$, the production of breast milk in the day 7 and 10 of $0.000,0.031(\mathrm{p}<0.05)$

Massage to stimulate the oxytocin hormone has a high effectiveness against changes in the
\end{abstract}

Keywords: Massage, Oxytocin, High Fundus uteri (TFU), Type lochea, Weight Babies

1),2),3), Prodi DIII Kebidanan Blora Poltekkes Kemenkes Semarang

Pada Tahun 2015 Program MDGs (Millenium Development Goals) belum mencapai target yang telah ditetapkan. Substainable Development Goals (SDGs) tahun 2030 merupakan pembangunan berkelanjutan dari MDGs tahun 2015. Target sistem kesehatan nasional dalam SDGs tahun 2030 yaitu menetapkan penurunan Angka Kematian Ibu dibawah 70 per 100.000 kelahiran hidup dan menurunkan Angka Kematian Neonatal 12 per 1.000 kelahiran hidup
(Kemenkes RI, 2014). Menghadapi tantangan dan target SDGs tersebut maka perlu adanya program kesehatan ibu dan bayi yang mampu menurunkan angka kesakitan dan kematian pada ibu dan bayi.

AKI Propinsi Jawa Tengah tahun 2012 sebesar 116,34 per 100.000 kelahiran hidup, mengalami peningkatan bila dibandingkan dengan AKI tahun 2011 sebesar 116,01 per 100.000 
kelahiran hidup. Kematian ibu sebesar $57,93 \%$ terjadi pada waktu nifas, $24,74 \%$ terjadi pada kehamilan, $17,33 \%$ pada persalinan (Dinas Kesehatan Propinsi Jateng, 2012). Penyebab kematian ibu pada waktu nifas diantaranya adalah karena perdarahan post partum. Salah satu penyebab utama perdarahan postpartum adalah atonia uteri, yaitu kegagalan mekanisme akibat gangguan fungsi miometrium. Upaya untuk mengendalikan terjadinya perdarahan dari tempat plasenta dengan memperbaiki kontraksi dan retraksi serat myometrium yang kuat dengan pijatan yang merangsang pengeluaran oksitosin. Oleh karena itu, upaya mempertahankan kontraksi uterus melalui pijatan untuk merangsang keluarnya hormone oksitosin merupakan bagian penting dari perawatan postpartum (Sutrisminah dan Nur; 2013). Hormon oksitosin ini sangat berperan dalam proses involusi uterus. Proses involusi akan berjalan dengan bagus jika kontraksi uterus kuat sehingga harus dilakukan tindakan untuk memperbaiki kontraksi uterus (Cuningham, 2006).

Penelitian yang dilakukan oleh Sarli, Masrul, Meilinda (2015) tentang pengaruh perbedaan kadar oksitosin melalui pemijatan oksitosin terhadap jumlah perdarahan pada ibu 2 jam post partum menunjukkan bahwa terdapat perbedaan yang bermakna antara jumlah perdarahan ibu 2 jam postpartum pada kelompok intervensi dan kelompok kontrol. Semakin tinggi kadar oksitosin maka jumlah perdarahan semakin sedikit. Oksitosin dapat diperoleh dengan berbagai cara baik melalui oral, intranasal, intramuscular, maupun dengan pemijatan yang merangsang keluarnya hormon oksitosin. Salah satu upaya yang bisa dilakukan untuk merangsang hormon prolaktin dan oksitosin pada ibu setelah melahirkan adalah dengan melakukan pijat oksitosin.

Beberapa hasil penelitian menunjukkan bahwa pijat untuk merangsang hormon oksitosin memilik manfaat untuk ibu nifas dan bayi. Menurut Lund, et al (2002) bahwa perawatan pemijatan berulang bisa meningkatkan produksi hormon oksitosin. Efek dari pijat oksitosin itu sendiri bisa dilihat reaksinya setelah 6-12 jam pemijatan. Pijat oksitosin berfungsi untuk menstimulasi sekresi oksitosin yang merangsang sekresi ASI. Oksitosin akan bekerja memacu refleks pengeluaran ASI atau refleks oksitosin yang disebut juga Let Down Reflex (LDR).

Berdasarkan penelitian Endah dan Imas (2011) pijat oksitosin berpengaruh terhadap jumlah produksi kolostrum menjadi lebih banyak. Penelitian yang serupa juga dilakukan oleh Albertina, Melly, Rahmawati (2015) bahwa terdapat hubungan yang signifikan antara pijat oksitosin dengan kelancaran produksi ASI. Berdasarkan hasil penelitian tersebut, saran yang diberikan kepada tempat pelayanan kesehatan adalah tetap menerapkan intervensi pijat oksitosin bagi ibu post partum untuk meningkatkan produksi ASI.

Data Riset Kesehatan Dasar (Riskesdas) tahun 2010 menunjukkan bahwa pemberian ASI di Indonesia saat ini memprihatinkan, presentase bayi yang menyusu eksklusif sampai dengan 6 bulan hanya 15,3\%. Hal ini disebabkan kesadaran masyarakat dalam mendorong peningkatan pemberian ASI masih relatif rendah (Sugiyarti, 2012). Berdasarkan PP No 23 tahun 2012 tentang pemberian Air Susu Ibu Eksklusif disebutkan bahwa pemberian ASI ekslusif bertujuan untuk menjamin 
pemenuhan hak bayi untuk mendapatkan ASI Ekslusif sejak lahir sampai batas berusia 6 (enam) bulan dengan memperhatikan pertumbuhan dan perkembangannya. Pemberian ASI saat ini masih terhalang dengan banyaknya kendala diantaranya adalah produksi ASI yang kurang lancar.

Berdasarkan hasil penelitian yang dilakukan oleh Rahmawati (2015) diketahui bahwa ada perbedaan pengeluaran ASI antara kelompok ibu yang mendapat pijat oksitosin dengan ibu yang tidak mendapat pijat oksitosin. Ibu post partum normal yang mendapat pijat oksitosin berpeluang memiliki pengeluaran ASI yang lebih lancar sebanyak 3.552 kali dibandingkan kelompok ibu post partum kontrol. Hal ini juga didukung oleh penelitian yang telah dilakukan oleh Khairani, Maria dan Wiwi (2011) yang mendapatkan hasil ada pengaruh pijat oksitosin terhadap involusi uterus pada ibu post partum.

Penelitian yang dilakukan oleh Venter dan Tara (2008) dalam Hanum, Yanik dan Ike (2015) menyatakan bahwa ASI mengandung zat imune modulator serta zat gizi yang unik. Selain itu, ASI mengandung zat gizi lengkap seperti karbohidrat berupa laktosa, lemak yang banyak (asam lemak tak jenuh ganda), protein utama berupa lactabumin yang mudah dicerna, kandungan vitamin dan mineral yang banyak.

Hasil studi pendahuluan melalui wawancara yang dilakukan pada beberapa bidan di Puskesmas wilayah Kabupaten Blora mereka mengatakan tidak pernah melakukan pijat untuk merangsang hormon oksitosin pada saat memberikan perawatan kepada ibu post partum, baik untuk merangsang kontraksi uterus, mengatasi perdarahan,

maupun merangsang keluarnya ASI. Berdasarkan hasil penelitian yang telah dilakukan oleh Hanum, Yanik dan Ike (2015) pijat oksitosin adalah salah satu cara untuk memperlancar dan meningkatkan produksi ASI. Pijat oksitosin merupakan salah satu contoh intervensi mandiri bidan dan dengan mudah dipilih dalam penatalaksanaan merangsang produksi ASI. Sehubungan dengan itu maka peneliti tertarik untuk meneliti lebih lanjut tentang efektivitas pijat untuk merangsang hormon oksitosin pada ibu nifas primipara.

\section{METODE}

Desain penelitian ini menggunakan quasi eksperiment dengan rancangan nonrandom with group control design.

Rancangan penelitian ini sebagai berikut :

Tabel 3.1.

Desain penelitian

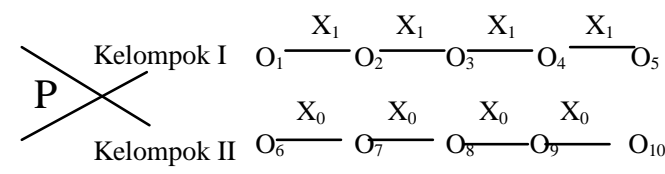

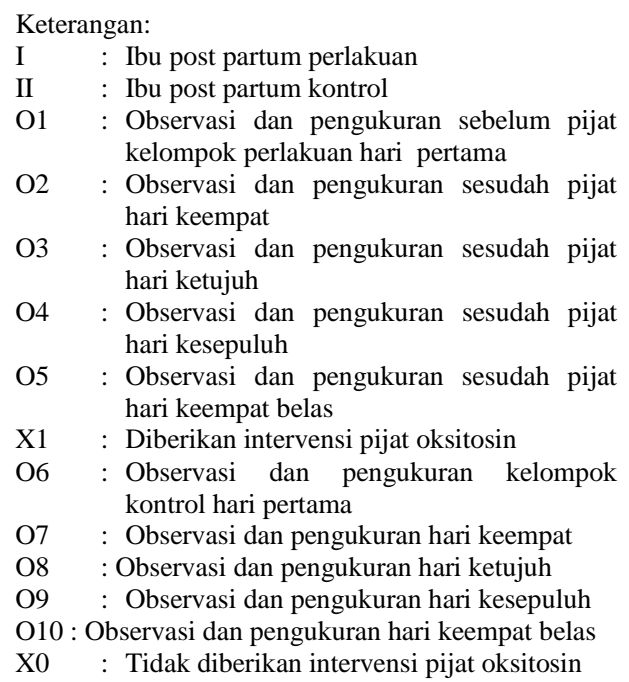




\section{HASIL DAN PEMBAHSAN}

Penelitian dilakukan oleh peneliti dengan dibantu oleh enumerator. Jumlah responden yaitu sebanyak 60 responden, 30 orang untuk kelompok kontrol dan 30 orang untuk kelompok perlakuan. Dari penelitian tersebut didapatkan hasil penelitian yang disajikan dalam bentuk analisa univariat dan bivariat.

\section{Analisis Univariat}

Karakteristik responden meliputi

Umur Ibu

Tabel 4.1

Distribusi umur responden

\begin{tabular}{ccccccc}
\hline \multirow{2}{*}{ Umur } & \multicolumn{2}{c}{ Kontrol } & \multicolumn{2}{c}{ Perlakuan } & \multicolumn{2}{c}{ Jumlah } \\
\cline { 2 - 7 } & $\mathrm{N}$ & $\%$ & $\mathrm{~N}$ & $\%$ & $\mathrm{~N}$ & $\%$ \\
\hline $\begin{array}{c}<20 \\
\text { tahun }\end{array}$ & 3 & $10 \%$ & 5 & $17 \%$ & 8 & $13,33 \%$ \\
$20-35$ & 27 & $90 \%$ & 25 & $83 \%$ & 52 & $86,67 \%$ \\
tahun & & & & & & \\
$>35$ & 0 & $0 \%$ & 0 & $0 \%$ & 0 & $0 \%$ \\
$\begin{array}{c}\text { tahun } \\
\text { Jumlah }\end{array}$ & 30 & $100 \%$ & 30 & $100 \%$ & 50 & $100 \%$ \\
\hline Sumber :(Data primer, 2016)
\end{tabular}

Berdasarkan tabel 4.1 menunjukkan bahwa umur sebagian besar res-ponden adalah 20-35 tahun yaitu 52 orang atau $86,67 \%$. Pada kelompok kontrol 27 orang, dan kelompok perlakukan 25 orang.

Pendidikan

Tabel 4.2

Distribusi pendidikan responden

\begin{tabular}{lcccccc}
\hline \multirow{2}{*}{$\begin{array}{l}\text { Pendidi } \\
\text { kan }\end{array}$} & \multicolumn{2}{c}{ Kontrol } & \multicolumn{2}{c}{$\begin{array}{c}\text { Perlakua } \\
\text { n }\end{array}$} & \multicolumn{2}{c}{ Jumlah } \\
\cline { 2 - 7 } & $\mathrm{N}$ & $\%$ & $\mathrm{~N}$ & $\%$ & $\mathrm{~N}$ & $\%$ \\
\hline SD & 1 & 3,33 & 3 & 10 & 4 & 6,67 \\
SMP & 1 & 46,6 & 8 & 26,6 & 22 & 36,6 \\
SMA & 4 & & 1 & 60 & 33 & 55 \\
D3/S1 & 5 & 50 & 8 & 60 & & \\
& 0 & 0 & 1 & 3,33 & 1 & 1,67 \\
Jumlah & 3 & $100 \%$ & 3 & 100 & 60 & 100 \\
& 0 & 0 & $\%$ & 6 & $\%$ \\
\hline Sumber : (Data Primer, 2016)
\end{tabular}

Berdasarkan tabel 4.2 menunjukkan bahwa pendidikan sebagian besar responden adalah SMA yaitu 33 orang atau $55 \%, 15$ orang pada kelompok kontrol dan 18 orang.

\section{Pekerjaan}

Tabel 4.3

Distribusi pekerjaan

\begin{tabular}{|c|c|c|c|c|c|c|}
\hline \multirow{2}{*}{$\begin{array}{c}\text { Peker } \\
\text { jaan }\end{array}$} & \multicolumn{2}{|c|}{ Kontrol } & \multicolumn{2}{|c|}{ Perlakuan } & \multicolumn{2}{|c|}{ Jumlah } \\
\hline & $\mathrm{N}$ & $\%$ & $\mathrm{~N}$ & $\%$ & $\mathrm{~N}$ & $\%$ \\
\hline IRT & 28 & 93,3 & 27 & 90 & 55 & 91,6 \\
\hline $\begin{array}{l}\text { Swas } \\
\text { ta }\end{array}$ & 2 & 6,6 & 3 & 10 & 5 & 8,3 \\
\hline PNS & 0 & 0 & 0 & 0 & 0 & 0 \\
\hline $\begin{array}{c}\text { Juml } \\
\text { ah }\end{array}$ & 30 & 100 & 30 & 100 & 60 & 100 \\
\hline
\end{tabular}

Berdasarkan tabel 4.3 menunjukkan bahwa pekerjaan sebagian besar responden adalah IRT yaitu 55 orang atau $91,67 \%$, yaitu 28 orang pada kelompok kontrol dan 27 orang pada kelompok perlakuan.

Perubahan Tinggi Fundus Uteri (TFU)

Tabel 4.4

Perubahan Tinggi Fundus Uteri

\begin{tabular}{lrrrr}
\hline \multirow{2}{*}{ Variabel } & \multicolumn{2}{c}{ Kelompok } & \multicolumn{2}{c}{ Kelompok } \\
& Kontrol & \multicolumn{2}{c}{ Perlakuan } \\
& Mean & Median & \multicolumn{1}{c}{ Mean } & Median \\
\hline TFU Hari 1 & 11.843 & 11.850 & 11.877 & 11.850 \\
TFU Hari 4 & 8.303 & 8.200 & 8.290 & 8.250 \\
TFU Hari 7 & 5.420 & 5.500 & 3.330 & 3.350 \\
TFU Hari & 2.043 & 2.000 & 0.877 & 1.000 \\
10 & & & & \\
TFU Hari & 0 & 0 & 0 & 0 \\
14 & & & & \\
\hline
\end{tabular}

Sumber : Data Primer (2016)

Berdasarkan tabel 4.4 menunjukkan bahwa selisih mean tertinggi Tinggi Fundus Uteri antara kelompok kontrol dan perlakuan terjadi pada hari ke-7 yaitu sebesar 2.09. 
Perubahan Jenis Lochea.

Tabel 4.5

Perubahan Jenis Lochea

\begin{tabular}{cc}
\hline Kelompok & Kelompok \\
Kontrol & Perlakuan
\end{tabular}

Variabel

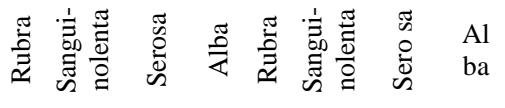

\begin{tabular}{|c|c|c|c|c|c|c|c|c|}
\hline $\begin{array}{l}\text { Lochea } \\
\text { Hari } 1\end{array}$ & $\begin{array}{l}3 \\
0\end{array}$ & 0 & 0 & 0 & $\begin{array}{l}3 \\
0\end{array}$ & 0 & 0 & 0 \\
\hline $\begin{array}{l}\text { Lochea } \\
\text { Hari } 4\end{array}$ & 4 & 26 & 0 & 0 & 0 & 28 & 2 & 0 \\
\hline $\begin{array}{l}\text { Lochea } \\
\text { Hari } 7\end{array}$ & 0 & 24 & 6 & 0 & 0 & 11 & 19 & 0 \\
\hline $\begin{array}{l}\text { Lochea } \\
\text { Hari } 10\end{array}$ & 0 & 6 & 23 & 1 & 0 & 0 & 14 & 16 \\
\hline $\begin{array}{l}\text { Lochea } \\
\text { Hari } 14\end{array}$ & 0 & 0 & 22 & 8 & 0 & 0 & 3 & 27 \\
\hline
\end{tabular}

Berdasarkan tabel 4.5 menunjukkan bahwa perubahan lochea antara kelompok kontrol dan perlakuan mulai terjadi pada hari ke-4.

\section{Perubahan Berat Badan Bayi}

Tabel 4.6

Distribusi perubahan berat badan bayi. (sampel lebih dari 50) dan didapatkan hasil nilai $\mathrm{p} 0,031 \quad(\mathrm{p}<0,05)$ sehingga data tidak berdistribusi normal. Uji yang digunakan adalah Mann Whitney. Untuk perhitungan perubahan TFU menggunakan uji Mann Whitney seperti pada tabel berikut ini.

Tabel 4.7

Hasil Uji Mann Whitney perubahan TFU

\begin{tabular}{llllll}
\hline & \multicolumn{5}{c}{ Perubahan TFU } \\
& Hari 1 & Hari 4 & Hari & Hari & Hari \\
& & & 7 & 10 & 14 \\
\hline $\begin{array}{l}\text { Mann- } \\
\text { Nhytney U }\end{array}$ & 435.000 & 445.500 & 296.50 & 190.50 & 404.00 \\
$\quad$ Wilcoxon W & 900.000 & 910.500 & 761.50 & 655.50 & 869.00 \\
Z & -1.000 & -.067 & -2.274 & -3.876 & -1.22 \\
Asymp.Sig.( & .317 & .946 & .023 & .000 & .222 \\
2-tailed) & & & & & \\
& & & & & \\
\hline Sumber : (SPSS.17.00) & & &
\end{tabular}

Tabel 4.7 menunjukkan perhitungan perubahan TFU kelompok kontrol dan perlakuan dengan Uji MannWhitney dengan hasil p-value (signifikansi) pada hari ke-1, ke-4 dan ke-14 sebesar $0.317,0.9460 .222$ ( $p>0.05)$, sehingga tidak ada perbedaan antara TFU pada kelompok kontrol dan perlakuan pada hari ke-1, ke-4 dan ke14. P-value pada hari ke-7 dan ke-10 Median sehingga ada perbedaan perubahan ${ }_{258.50}^{54.00}$ antara kelompok kontrol dan 18efdakukan pada hari ke-7 dan ke-10. 8\$.ghingga $\mathrm{H}_{\mathrm{a}}$ diterima dan $\mathrm{H}_{0}$ ditolak. Dengan demikian pijat untuk merangsang hormon oksitosin memiliki efektifitas terhadap tinggi fundus uteri pada ibu nifas primipara. Untuk perhitungan perubahan lochea menggu-nakan uji Mann Whitney seperti berikut ini. 
Tabel 4.8

Hasil Uji Mann Whitney perubahan Lochea

\begin{tabular}{llllll}
\hline & & \multicolumn{5}{c}{ Lochea } \\
& Hari 1 & Hari 4 & Hari 7 & $\begin{array}{l}\text { Hari } \\
10\end{array}$ & $\begin{array}{l}\text { Hari } \\
14\end{array}$ \\
\hline $\begin{array}{l}\text { Mann- } \\
\text { Whytney U }\end{array}$ & 450.00 & 364.00 & 255.00 & 183.00 & 165.00 \\
Wilcoxon W & 915.00 & 829.00 & 720.00 & 648.00 & 630.00 \\
Z & .000 & -2.444 & -3.376 & -4.583 & -4.934 \\
$\begin{array}{l}\text { Asymp.Sig.( } \\
\text { 2-tailed) }\end{array}$ & 1.000 & .015 & .001 & .000 & .000 \\
& & & & & \\
\hline Sumber : (SPSS 17.00) & & & &
\end{tabular}

Tabel 4.8 menunjukkan perhitungan perubahan lochea kelompok kontrol dan perlakuan dengan Uji Mann-Whitney dengan hasil p-value (signifikansi) pada hari ke-1 sebesar 1.000 ( $p>0.05)$, sehingga tidak ada perbedaan antara TFU pada kelompok kontrol dan perlakuan pada hari ke-1. $P$-value pada hari ke-4, ke-7, ke-10 dan ke-14 didapatkan hasil 0.015, 0.001, $0.000,0.000 \quad(\mathrm{p}<0.05) \quad$ sehingga ada perbedaan perubahan lochea pada kelompok kontrol dan perlakukan pada hari ke-4, ke-7, ke-10 dan ke-14. Sehingga $\mathrm{H}_{\mathrm{a}}$ diterima dan $\mathrm{H}_{0}$ ditolak. Dengan demikian pijat untuk merangsang hormon oksitosin memiliki efektifitas terhadap jenis lochea pada ibu nifas primipara. Untuk perhitungan perubahan kenaikan berat badan bayi menggunakan uji Mann Whitney seperti pada tabel berikut ini.

Tabel 4.9

Hasil Uji Mann Whitney perubahan kenaikan berat badan

\begin{tabular}{|c|c|c|c|c|c|}
\hline & \multicolumn{5}{|c|}{ Kenaikan Berat Badan } \\
\hline & Hari 1 & $\begin{array}{l}\text { Hari } \\
4\end{array}$ & Hari 7 & Hari 10 & Hari 14 \\
\hline $\begin{array}{l}\text { Mann- } \\
\text { Whytne } \\
\text { y U }\end{array}$ & 450.00 & $\begin{array}{l}365.5 \\
0\end{array}$ & 103.50 & 304.00 & 432.50 \\
\hline $\begin{array}{l}\text { Wilcox } \\
\text { on W }\end{array}$ & 915.00 & $\begin{array}{l}821.5 \\
0\end{array}$ & 568.50 & 769.00 & 897.50 \\
\hline $\mathrm{Z}$ & .000 & -1.38 & -5.128 & -2.160 & -.259 \\
\hline $\begin{array}{l}\text { Asymp. } \\
\text { Sig.(2- } \\
\text { tailed) }\end{array}$ & 1.000 & .167 & .000 & .031 & .796 \\
\hline
\end{tabular}

Sumber : (SPSS.17.00)
Tabel 4.9 menunjukkan perhitungan perubahan produksi ASI yang diukur dengan perubahan kenaikan berat badan bayi pada kelompok kontrol dan perlakuan dengan Uji Mann-Whitney dengan hasil p-value (signifikansi) pada hari ke-1, ke-4, ke-14 sebesar 1.000, 0.167, 0.796 ( $>>0.05)$, sehingga tidak ada perbedaan antara produksi ASI pada kelompok kontrol dan perlakuan pada hari ke-1, ke-4 dan ke14. P-value pada hari ke-7 dan ke-10 didapatkan hasil 0.000, $0.031(\mathrm{p}<0.05)$ sehingga ada perbedaan perubahan produksi ASI pada kelompok control dan perlakukan pada hari ke-7 dan ke10.

Sehingga $\mathrm{H}_{\mathrm{a}}$ diterima dan $\mathrm{H}_{0}$ ditolak. Dengan demikian pijat untuk merangsang hormon oksitosin memiliki efektifitas terhadap produksi ASI pada ibu nifas primipara.

\section{PEMBAHASAN}

Mayoritas responden berada pada kelompok umur reproduktif (2035 tahun) yaitu sebanyak 52 orang $(86,7 \%), 27$ responden dari kelompok kontrol dan 25 responden dari kelompok perlakuan. Pada penelitian ini, faktor usia juga bisa mempengaruhi penurunan uterus. Ibu dengan kondisi usia yang lebih tua banyak dipengaruhi oleh proses penuaan, adanya perubahan metabolisme akan menghambat proses involusi uterus (Kautsar, 2011). Meningkatnya umur seseorang akan semakin berkurang fungsi reproduksinya dan keelastisitasan otot-otot organ reproduksi (Liana, 2013).

Status pendidikan responden, sebagian besar berada pada pendidikan SMA yaitu sebanyak 33 orang (55\%), 15 responden dari kelompok 
kontrol dan 18 responden dari kelompok perlakuan.

Status pekerjaan responden sebagian besar adalah Ibu Rumah Tangga, yaitu sebanyak 55 orang $(91,7$ $\%), 28$ responden dari kelompok kontrol dan 27 responden dari kelompok perlakuan.

Hasil analisis uji Mann Whitney pada tinggi fundus uterus hari ke 1 , hari ke 4 dan hari ke 14 menunjukkan $p$ value $>0,05$ masing-masing yaitu 0,317 , 0,946 dan 0,222 . Hal ini menunjukkan bahwa tidak ada perbedaan TFU antara hari ke 1 , hari ke 4 dan hari ke 14 untuk kelompok yang mendapat perlakuan dan kelompok kontrol. Hal ini dapat dilihat dari nilai rerata pada kelompok kontrol lebih besar daripada nilai rerata pada kelompok perlakuan. Lain halnya dengan TFU hari ke 7 dan hari ke 10 yang menunjukkan $p$-value $<0,05$ masing-masing yaitu 0,023 dan 0,0001 ; dimana berarti ada perbedaan tinggi fundus uterus antara hari ke 7 dan hari ke 10. Hal ini dapat dilihat dari nilai rerata pada kelompok perlakuan lebih besar daripada nilai rerata pada kelompok kontrol untuk ketiganya. Pijat untuk merangsang oksitosin berpengaruh terhadap penurunan tinggi fundus uterus. Oksitosin yang dihasilkan oleh hipofisis posterior akan masuk ke dalam sirkulasi darah dan bekerja pada otot otot uterus, sehingga dapat membantu proses involusi uterus (Sibagariang, 2010).

Teori pada umumnya, bahwa hari ke 5 - 7 penurunan tinggi fundus berada pada pertengahan simpisis pubis dan pusat. Teori lain menyebutkan bahwa penurunan tinggi fundus uteri pada masa nifas terjadi penurunan $1 \mathrm{~cm}$ selama 1 hari postpartum, $6 \mathrm{~cm}$ di bawah pusat selama 6 hari postpartum (Manuaba, 2007). Perbedaan antara teori dan hasil penelitian ini membuktikan bahwa dengan adanya pengaruh pijat oksitosin dapat mempercepat penurunan tinggi fundus uteri dari kondisi normal pada umumnya. Hal ini dikarenakan adanya peningkatan hormon oksitosin pada ibu nifas primipara setelah diberikan intervensi berupa pijatan. Pernyataan ini didu-kung oleh hasil penelitian oleh Lisni Andeka dkk pada tahun 2015 bahwa pemberian pijat oksitosin mengalami percepatan pencapaian waktu involusi uterus. Selain pernyataan di atas, oksitosin ternyata juga mampu mengi-kat aktin miosin dalam otot uterus sehingga kontraksi uterus semakin uat, dan proses involusi uterus semakin bagus (Jordan, 2004).

Hasil analisis uji Mann Whitney pada pengeluaran lokhea hari ke 1 menunjukkan $p$-value $>0,05$. Hal ini berarti bahwa tidak ada perbedaan lokhea antara hari ke 1 dan hari ke 4. Lain halnya dengan pengeluaran lokhea pada hari ke 4, hari ke 7, hari ke 10 dan hari ke 14 yang menunjukkan $p$-value $<0,05$ masing-masing yaitu 0,015 ; 0,$001 ; 0,0001$ dan 0,0001. Hal ini berarti ada perbedaan pengeluaran lokhea antara hari ke 4, hari ke 7, hari ke 10 dan hari ke 14 pada kedua kelompok. Perubahan pada hari ke 7 dapat dilihat bahwa pada kelompok kontrol jumlah responden yang masih mengeluarkan lokhea sanguinolenta sebanyak 24 responden dan lokhea serosa sebanyak 6 responden, sedangkan pada kelompok perlakuan jumlah responden yang masih mengeluarkan lokhea sanguinolenta sebanyak 11 responden dan lokhea serosa sebanyak 19 responden, begitu juga dengan perubahan hari ke 4, hari ke 10 dan hari ke 14. Hal ini merupakan pembuktian adanya pengaruh pijat untuk merang- 
sang oksitosin terhadap pengeluaran lokhea. Meningkatnya hormon oksitosin akan mengurangi jumlah perdarahan. Dengan adanya involusi uterus, lapisan luar desidua yang mengelilingi plasenta akan menjadi nekrotik dan melebur. Desidua yang mati akan akan keluar bersama dengan sisa cairan (Marni, 2012). Semakin cepat proses involusi, makan akan semakin cepat perubahan pengeluaran lokhea (Rincci, 2009). Jika ibu mendapatkan rangsangan oksitosin, pengeluaran lokhea akan mengalami perubahan dengan cepat dari periode normalnya. Pengeluaran lokhea dapat dipengaruhi dengan aktivitasi mobilisasi dan menyusui (Crum, 2010).

Berdasarkan uji Mann Whitney pada data berat badan didapatkan perbedaan berat badan bayi antara kelompok kontrol dan kelompok perlakuan pada hari ke 7 dan hari ke 10 , dibuktikan dengan nilai $p$ value $<0,05$. Perubahan pada hari ke 7 dan ke 10 adanya peningkatan berat badan yang lebih besar pada kelompok perlakuan daripada peningkatan berat badan pada kelompok kontrol. Peningkatan berat badan bayi merupakan salah satu indikator kecukupan produksi ASI. Salah satu tanda bayi tidak cukup mendapat ASI adalah pertambahan berat badan kurang, bayi kehilangan berat badan lebih dari $10 \%$ dari berat lahir atau kurang dari berat lahir saat usia 2 minggu (WHO, 2011). Hasil penelitian ini membuktikan bahwa adanya intervensi pijat untuk merangsang hormon oksitosin mampu memperbanyak produksi ASI yang dalam hal ini diukur dari peningkatan berat badan bayi. Pijat oksitosin merangsang refleks let down untuk mensekresi hormon oksitosin ke dalam darah sehingga menyebabkan sel-sel miopitelium di sekitar alveoli berkontraksi dan membuat ASI mengalir dari alveoli ke duktus menuju sinus dan putting yang nantinya akan dihisap oleh bayi. Pijat oksitosin selain bermanfaat untuk merangsang hormon oksitosin juga bermanfaat untuk membuat ibu rileks, lebih nyaman, mengurangi kelelahan setelah melahirkan (Mardiyaningsih, 2010).

\section{SIMPULAN}

Rata-rata perubahan Tinggi Fundus Uteri (TFU) pada ibu nifas primipara tertinggi pada hari ketujuh, pada kelompok kontrol sebesar 5,420 dan kelompok perlakuan sebesar 3,330 atau terdapat perbedaan penurunan sebesar 2,090 cm.

Jenis lochea pada kelompok kontrol dan perlakuan pada hari kesatu adalah lochea rubra. Jenis lochea kelompok kontrol pada hari keempat adalah lochea rubra dan sanguinolenta, sedangkan pada kelompok perlakuan adalah lochea sanguinolenta dan serosa. Jenis lochea kelompok kontrol dan perlakuan pada hari ketujuh adalah lochea sanguinolenta dan serosa. Jenis lochea kelompok kontrol pada hari kesepuluh adalah lochea sanguinolenta, serosa, alba sedangkan pada kelompok perlakuan adalah lochea serosa dan alba. Jenis lochea kelompok kontrol dan perlakuan pada hari keempat belas adalah lochea serosa dan alba.

Produksi ASI yang ditandai dengan selisih kenaikan berat badan bayi hari keempat pada kelompok kontrol dan perlakuan memiliki mean sebesar $-5,747$ dan 35,13 atau terdapat perbedaan kenaikan sebesar 40,6 gram.

Selisih kenaikan berat badan bayi hari ketujuh pada kelompok kontrol dan perlakuan memiliki mean sebesar 33,60 dan 231,87 atau terdapat perbedaan kenaikan sebesar 198,27 
gram. Selisih kenaikan berat badan bayi hari kesepuluh pada kelompok kontrol dan perlakuan memiliki mean sebesar 40.47 dan 80,03 atau terdapat perbedaan kenaikan sebesar 39,56 gram. Selisih kenaikan berat badan bayi hari keempat belas pada kelompok kontrol dan perlakuan memiliki mean sebesar 110,00 dan 106,00 atau terdapat perbedaan kenaikan sebesar 4 gram.

Pijat untuk merangsang hormone oksitosin memiliki efektivitas terhadap perubahan tinggi fundus uteri pada ibu nifas primipara hari ke-7 dan ke-10 berdasarkan uji Man-Whitney dengan nilai sig sebesar 0.023 dan 0.0001 $(\mathrm{p}<0,05)$.

Pijat untuk merangsang hormone oksitosin memiliki efektivitas terhadap perubahan jenis lochea pada ibu nifas primipara hari ke-4, ke-7, ke-10 dan ke-14 berdasarkan uji Man-Whitney dengan nilai sig $0.015,0.001,0.000$, $0.000(\mathrm{p}<0.05)$.

Pijat untuk merangsang hormone oksitosin memiliki efektivitas terhadap produksi ASI hari ke-7 dan ke-10 berdasarkan uji Man-Whitney dengan nilai sig 0.000, $0.031(\mathrm{p}<0.05)$.

\section{SARAN}

Bagi Klien

Untuk suami dan keluarga ibu post partum dapat membantu melakukan pijat untuk merangsang hormone oksitosin sampai masa nifas selesai, karena dapat membantu mempercepat pemulihan kondisi rahim selama masa nifas dan produksi ASI untuk bayi tercukupi. Bagi Masyarakat

Masyarakat hendaknya lebih mengenal manfaat pijat untuk merangsang hormone oksitosin sehingga dapat mendorong ibu untuk mendapatkan asuhan masa nifas dengan pijat untuk merangsang hormone oksitosin untuk mempercepat pemulihan rahim ibu post partum dan produksi ASI untuk bayi tercukupi.

Bagi Institusi Puskesmas

Diharapkan institusi Puskesmas dapat mengadakan program pijat untuk merangsang hormone oksitosin dan meningkatkan promosi kepada ibu dengan cara memfasilitasi dengan media leaflet atau papan yang ditempel di dinding ruangan nifas yang berisi gerakan pijat untuk merangsang hormone oksitosin dan mengajarkan teknik pijat ke keluarga pasien.

\section{DAFTAR PUSTAKA}

Albertina, M, Melly, Rahmawati Shoufiah. 2015. Hubungan Pijat Oksitosin Dengan Kelancaran Produksi ASI Pada Ibu Post Partum Seksio Sesarea Hari Ke 2-3. Jurnal Husada Mahakam Volume III No.9, Mei 2015, Hal 452-521

Cunningham,F.G, Mc Donald, P.C.Grant, N.F. 2006. Obstetri Williams. Penerjemah : Suyono \& Hartono. Jakarta: EGC

Crum, Kelly. 2010. Maternal Psycologhic Changes. Whasington : Association of Women Health Obstetric and Neonatal Nurses.

Dinas Kesehatan Provinsi Jawa Tengah. Profil Kesehatan Provinsi Jawa Tengah Tahun 2012. Didapat dari http://www.depkes.go.id diakses tanggal 01/02/2016

Dinas Kesehatan Rembang. 2014. Profil Kesehatan Kabupaten Rembang Tahun 2014

Endah Siti Nur, Imas Masdinarsah. 2011. Pengaruh Pijat Oksitosin terhadap Pengeluaran Kolostrum 
pada Ibu Post Partum di Ruang Kebidanan Rumah Sakit Muhammadiyah Bandung. Jurnal Kesehatan Kartika.

Hamranani, Sri Sat Titi. 2011. Penga ruh Pijat Oksitosin Terhadap Involusi Uterus Pada Ibu Post Partum Dengan Persalinan Lama Di Rumah Sakit Wilayah Kabupaten Klaten. Motorik Jurnal Ilmu Kesehatan (Journal of Health Science) Vol 6, No 12 2011

Hanum, Sri Mukhodim Faridah, Yanik Purwanti, Ike Rohmah Khumairoh. 2015. Efektifitas Pijat Oksitosin terhadap Produksi ASI. Midwiferia/Vol.1; No.1/April 2015

Huliana, M., 2003. Perawatan Ibu Pasca Melahirkan. Jakarta : Puspa Swara

Isnaini, Nurul, Rama Diyanti. 2015. Hubungan Pijat Oksitosin Pada Ibu Nifas Terhadap Pengeluaran ASI Di Wilayah Kerja Puskesmas Raja Basa Indah Bandar Lampung Tahun 2015. Jurnal Kebidanan Vol 1, No 2, Juli 2015 : 91-97

Jordan. S. 2004. Obat yang Meningkatkan Kontraksilitas Uterus atau Oksitosin. Dalam Ester. M. (Ed) Farmakologi Kebidanan. Jakarta : Penerbit Buku Kedokteran EGC

Kementerian Kesehatan RI. Profil Kesehatan Indonesia Tahun 2014. Jakarta: Kementrian Kesehatan Republik Indonesia

Khairani Leli, Maria Komariah, Wiwi Mardiah. 2011. Pengaruh Pijat Oksitosin Terhadap Involusi Uterus pada Ibu Post Partum Kelas III RSHS Bandung. Bandung: Fakultas Ilmu Keperawatan Universitas Padjadjaran
Liana, 2013. Faktor-faktor Yang Mempengaruhi Tinggi Fundus Uterus pada Ibu Postpartum di $R S$ Umum $d r$. Zainal Abidin Banda Aceh. Stikes U'budaiyah Banda Aceh.

Lisni, Andeka, Misrawati, Gamya Tri Utami. 2015. Perbandingan Efektivitas Senam Nifas dan Pijat Oksitosin terhadap Involusi Uterus pada Ibu Postpartum. JOM Volume 2 No 2 Oktober 2015.

Lund, I; Moberg, U; Wang, J; Yu, C; Kurosawa, M. 2002. Massage affect nociception of oxytocin. J.European neuroscience $\mathrm{Vol}$ $16: 330-338$

Manuaba. 2007. Pengantar Kuliah Obstetri Cetakan I. Jakarta: EGC.

Mardiyaningsih, Eko, Setyowati, Luknis Sabri. 2011. Efektifitas kombinasi teknik marmet dan pijat oksitoksin terhadap produksi ASI ibu post SC di RS wilayah Jawa Tengah. Jurnal Keperawatan Soedirman (The Soedirman Journal of Nursing) Volume 6, No.1, Maret 2011

Marmi.2012. Asuhan Kebidanan pada Masa Nifas. Yogyakarta: Pustaka Pelajar.

Nurchayati. 2012.Manfaat Massaging Nape (Pemijatan Tengkuk) Terhadap Pengeluaran ASI Pada Ibu Nifas Di RSUD Cilacap

Pilliteri.(2003). Meternal and child health nursing.Buku I. Fourth edition. Philadelphia: Lippincott

Prawirohardjo, S.2009. Ilmu Kebidanan. Jakarta: Yayasan Bina Pustaka Sarwono Prawirohardjo.

Rahmawati, Eli. Hubungan Pijat Oksitosin Dengan Pengeluaran ASI 
Pada Ibu Post Partum Hari 1-2 Di BPM HJ.NL Kota Balikpapan. Jurnal Husada Mahakam Volume III No.8 November 2014 hal 389 442

Rincci, S. S. 2009. Esential of Maternity Newborn and Women Health Nursing $2^{\text {nd }}$ edition. China : Lipincot Williams and Walkins.

Safrina, Renny sinaga, Yusliana Nainggolan. 2016. Perbedaan Efektivitas Antara Pijat Oksitosin Dan Pijat Payudara Terhadap Involusi Uteri Pada Ibu Post Partum Di BPM Kota Pematangsiantar Tahun 2015. Jurnal Penelitian Kesehatan Suara Forikes Volume VII Nomor 1, Januari 2016 ISSN:2086-3098

Saleha, Siti. 2009. Asuhan Kebidanan Pada Masa Nifas. Jakarta: Salemba Medika.

Sibagariang, E. E dkk.2010. Kesehatan Reproduksi Wanita. Jakarta : CV. Trans Info Media

Sudigdo Sastroasmoro. 2010. Dasar dasar Metodologi Penelitian Klinis edisi ke-4. Sagung Seto. Jakarta

Sugiyarti, I. 2012. Hubungan Pendidikan Dan Pengetahuan Ibu Hamil Tentang Manfaat ASI Eksklusif Dengan Motivasi Ibu Untuk Memberikan ASI Eksklusif (Studi KasusDi Puskesmas Candilama Kota Semarang).Di dapat dari: http://digilib.unimus.ac.iddiakses tanggal 01 Februari 2016

Suherni, S. dkk.(2008). Perawatan Masa Nifas. Yogyakarta: Fitramaya.

Sulistyaningsih. (2011). Metodologi Kebidanan Kuantitatif Kualitatif. Yogyakarta: Graha Ilmu.
Sutrisminah, Emi, Nur Alfiyati. 2013. Benefits of Breast Massage on Postpartum Uterine Involution. Jurnal Involusi Kebidanan, Vol.3 No.5, Januari 2013

Varney, Helen. dkk. (2007). Buku Ajar Asuhan Kebidanan. Jakarta: EGC. 